\title{
New Direction to the Sustainable Development Goals in Job Creation Bill in Indonesia
}

\author{
Anggita Doramia Lumbanraja*
}

Faculty of Law, Universitas Diponegoro, Semarang, Indonesia

\begin{abstract}
United Nations Sustainable Development Goals (UN SDGs) deliver a long list for UN Member countries to do, especially in the legal and regulatory frameworks. UN SDGs contain many kinds of human needs aspect, and it is not easy to regulate all through the conventional legislative process. It raises the needs of the omnibus bill use. This article studied the opportunities and the urgency of the omnibus bill use to solve this problem. The author uses a doctrinal method with literature studies to examine how SDGs can be obtained with the use of the omnibus bill. The omnibus bill has the potential to help countries achieve the UN SDGs. In the implementation stage, the author found that it is a normal phenomenon that a political will contains economic interests in the adaptation process, likewise, with the omnibus bill case in several countries. However, it does not erase the fact that there has been a wave of resistance in its implementation due to people's unpreparedness in accepting changes brought by the political policies that are contained in the controversial omnibus bill. Therefore, the government must ensure that the omnibus bill is open to the change opportunities demanded by the people to improve the omnibus bill.
\end{abstract}

Keywords: Job Creation Law, Omnibus Bill; Politics of law; Legal Changes; Sustainable Development Law.

\section{INTRODUCTION}

The omnibus bill usage was marked as unorthodox lawmaking (Sinclair, 1997), breaking the traditional lawmaking in the conventional legislative process (Gluck et al., 2015). It is commonly found in parliamentary countries (Bédard, 2012) with the domination of the common law system. The omnibus bill is seen as a solution to solve the difficulties of legislative processes through common law advances (King, 1997), and it has been used by several countries to improve legislative productivity (Krutz, 2000).

In 2008, the global financial crisis affected worldwide with global economic shock and the economic recession. The regulation became an essential factor in facilitating markets and financial institutions to come out from the financial crisis (French et al., 2009). This was going to be the reason for Europeans to use the Omnibus Law as a policy tool in solving financial crisis issues after the global financial crisis in 2008 (Maloney, 2011).

In some countries, the omnibus law is endorsed as a deregulation and simplification tool to reduce and simplify the excessive statutory regulations. Moreover, in Luxemburg (Elvinger Hoss, 2017) French et al., 2009; Hainque \& Montin, 2011), where are known as the civil law system countries, have been enacted omnibus simplification laws to simplify regulation and

*Address correspondence to this author at the Faculty of Law, Universitas Diponegoro, Semarang, JI. Prof. Soedarto, Tembalang, Semarang, Central Java 50275, Indonesia; E-mail: adlumbanraja.undip@gmail.com bureaucracy for a better regulation (OECD, 2010 ${ }^{\mathrm{a}}$ ) (OECD, 2010 ).

The resolution of regulation quantities and investment climate problems has become a major priority for President Joko Widodo's (President of the Republic of Indonesia) political will in law. President Joko Widodo initiated the omnibus bill on job creation to improve the regulation to enhance investment climate, by amending 73 laws (Samboh, 2020). This is because Indonesia has been stuck at $73^{\text {rd }}$ in the World Bank's ease of doing business ranking since 2018 (Rahman, 2020). Meanwhile, on the other hand, Indonesia Omnibus Bill on Job Creation became a controversial bill, as it has gained mass protests, especially from labor unions (Akhlas et al., 2020). However, the omnibus bill is a viable method for regulatory reform to be more effective and efficient.

The social dynamics and developments in Indonesia have brought the legal system into a crossroads. Social interest brings the legal system into a different side of the legal facet. This happens because of social changes, due to globalization's effect (Perrons, 2004) that brings international economic integration (economic globalization), international political integration (political globalization), global culture formation (cultural globalization/geo-culture) (Chase Dunn \& Lerro, 2014). All these things create borderless interaction for the global civil society.

On the other side, international law instruments such as international covenant, treaties, conventions, agreements, declarations, resolutions or protocol, influence legal rules and the legal system in Indonesia 
that makes a legal change. Legal changes could not be denied, as the implementation of international law instruments needs international law approaches.

United Nations (UN) Resolution, called the "2030 Agenda", set 17 goals over people, planet, prosperity, peace, and partnership crucial issues which intended to be achieved in 2030. 2030 Agenda as we known as United Nations Sustainable Development Goals (UN SDGs), followed by the commitment of the Member States of UN to implement those goals in real actions. Long before that in 1990, Agenda 21, the Rio Declaration on Environment and Development, and the Statement of principles for the Sustainable Management of Forests were adopted by more than 178 Governments at the United Nations Conference on Environment and Development (UNCED) (the blueprint of action to achieve sustainable development) in chapter 8B urges to make laws and regulations, judicial and administrative procedure more effective (Futrell, 2004a). The implementation of Sustainable Development Laws required social progress in the existing laws through decision maker policies, as the bridge of transition into the sustainable development goals (Futrell, 2004b).

Indonesia, as one of United Nations Member, has committed to achieving the 2030 Agenda. In accelerating action on The Sustainable Development Goals, Indonesia needs to put this as part of the Indonesia Administration's political will, where it becomes embodied in Indonesia politics of law. Indonesia has accommodated some Sustainable Development issues in The National Action Plan. However, a huge amount of regulations and the convoluted bureaucracy based on the old paradigm of public service, would not make this National Action Plan work. It requires a new approach to the lawmaking process in Indonesia based on this politics of law, and the omnibus bill is an alternative solution that might be taken.

This legal research aims to discuss the omnibus bill's role in supporting a government in achieving sustainable development goals. In this research, the author examines how the Indonesian governments are trying to apply the omnibus bill as a new approach in the law-making process.

\section{METHODS}

This research is legal in the science of law field. This research uses a doctrinal methodology with the literature study. The author examined the expository materials and secondary data material from legislation, journals, thesis, textbooks, reports, International Law instruments, conventions, and statutes related to Omnibus Law and United Nations Sustainable Development Goals (UN SDGs).

\section{RESULTS AND DISCUSSION}

According to The Brundtland Commission, the concept of Sustainable Development gives the most priority to the essential needs of poverty in this world and the limitation of the natural resources exploration (environmental protection and natural resources management) to meet the needs of present and future generations (WCED, 1987). So, sustainable development is closely related to humanity and environmental issues in the Economy and Environment subject area.

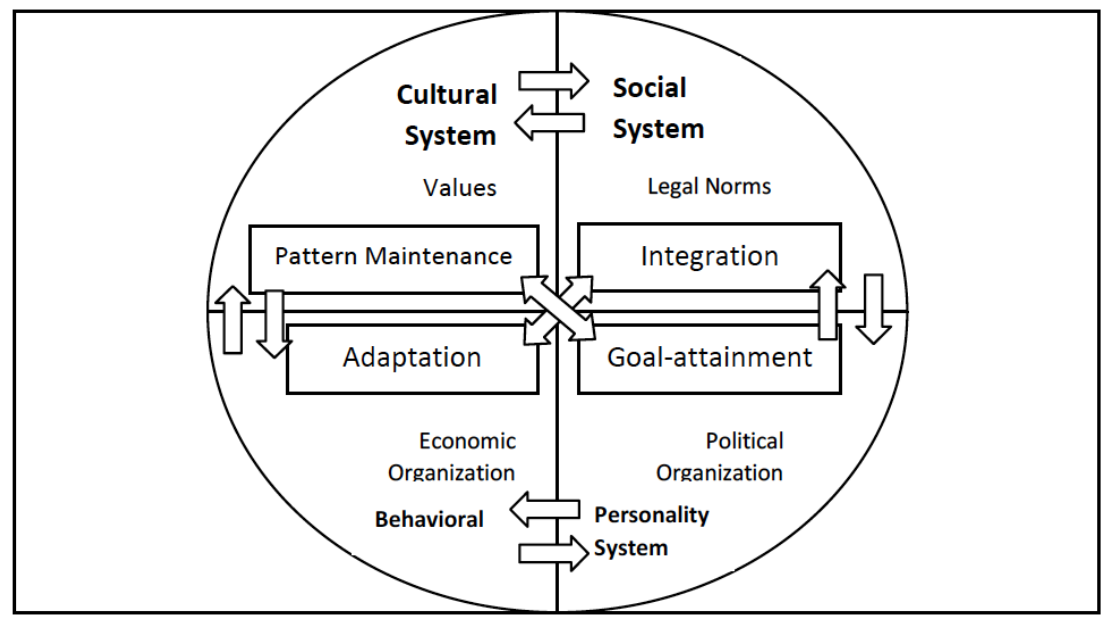

Figure 1: Parsons' Cybernetic Control Concept.

Source: Parsons, (1961). 
If we are going to discuss the implementation of sustainable development in a particular social system, it is relevant to consider Parsons' Cybernetic system control concept. Parsons found that there is a relation between goal attainment and adaptation in the social system. Both of them are concern about structures, mechanisms, and processes. Furthermore, in the case of goal plurality attainment, the cost problem will be occurred, because pursuing one goal will sacrifice another goal. So that is why adaptation function in the social system focused on the economic issues, whether on the other side the goal attainment focused on political issues of the society (Parsons, 1961).

From Parson's concept, Economic Organization and Political Organization have a strong relationship, although Political Organization is more prominent than Economic Organization because goal-attainment is a more important control than adaptation (Parsons, 1961). So it will not be surprised that when we discuss the politics of law, the substance of politics of law will refer to the economic interests because they support each other's function.

To set the seventeen sustainable development goals in a social system, we will not be able to ignore the economic issues. It is because when these 17 goals being designed in the Politics of law, still we have to consider the economic factors. This has become commonplace for Indonesia to make their first omnibus bill for the sake of creating a conducive economic atmosphere, in this case, an investor-friendly economic atmosphere.

As a sign of the Indonesian government's commitment to implementing the achievement of the Sustainable Development Goals, the Government of Indonesia has issued Indonesia Government Regulation Number 59 of 2017 on the Implementation of the Sustainable Development Goals Achievement, shown in Table 1 below. In this regulation, the
Sustainable Development Goals are aligned with the National Long-Term Development Plan and the National Medium-Term Development Plan.

However, it seems that those documents are not working effectively to accelerate the achievement of SDGs. In 2020 Indonesia's position on the SDG Index Rank in the 101st position, under the six other Southeast Asian countries. They are Thailand in the 41st position, followed by Vietnam, Malaysia, Brunei Darussalam, Singapore, and the Philippines, as shown in Table 2 below. Furthermore, Indonesia has not achieved any goals of the seventeen points of the SDGs. The Indonesian government should make substantial progress to take the action plan into the proper regulations or policy documents for the Sustainable Development Goals in 2003. There are remaining many tasks that must be addressed by the government.

There are seven points from the seventeen SDGs points that remain still far from the achievement, as we saw in Table 3. They are the point of number 2, about zero hunger goal; the point of number 3 , about good health and well-being; the point of number 6 , about clean water and sanitation goal; the point of number 9 , about the industry, innovation, and infrastructure goal; point of number 10 , about the reduction of inequality goal; the point of number 15, about life on land goal; and the point of number 17 , about the partnerships for the goals. To achieve these seven goals, Indonesia should pursue infrastructure development by creating a conducive economic condition. In pursuing to implement several strategic plans at the same time by considering cutting the cumbersome bureaucracy and bringing all the rule of law under one legal umbrella, Indonesia can use the omnibus bill to set several regulations at once.

In pursuing those indicators in Table 3, Indonesia should create an investor-friendly economic

Table 1: Related Documents in Making of the SDGs Action Plan

\begin{tabular}{|c|c|}
\hline No. & Documents \\
\hline \hline 1 & Medium-Term National Development Plan 2015-2019 \\
\hline 2 & the strategic plan of Ministries/Non-Ministries 2015-2019 \\
\hline 3 & Presidential Regulation No. 59 of 2017 on Implementing the Achievement of the Sustainable Development Goals \\
\hline 4 & Report on The Achievement of Millennium Development Goals Indonesia, 2000-2015 \\
\hline 5 & Other related Policy Documents \\
\hline 6 &
\end{tabular}

Source: BAPPENAS, (2017). 
Table 2: Southeast Asia Countries in SDG Index Score and World Rank 2020

\begin{tabular}{|c|c|c|c|c|}
\hline No & Countries & Score (2020) & $\begin{array}{c}\text { World SDG } \\
\text { Rank }\end{array}$ & $\begin{array}{c}\text { SDG Achievement } \\
\text { (17 SDGs point) }\end{array}$ \\
\hline \hline 1 & Thailand & 74,54 & 41 & $(1)$ \\
\hline 2 & Vietnam & 73,80 & 49 & $(1)$ \\
\hline 3 & Malaysia & 71,76 & 60 & - \\
\hline 4 & Brunei Darussalam & 68,15 & 88 & $(12),(13)$ \\
\hline 5 & Singapore & 67,00 & 93 & $(12),(7),(9)$ \\
\hline 6 & Philippines & 65,50 & 99 & - \\
\hline 7 & Indonesia & 65,30 & 101 & $(12)$ \\
\hline 8 & Myanmar & 64,58 & 104 & $(12),(13)$ \\
\hline 9 & Cambodia & 64,39 & 106 & $(12),(13)$ \\
\hline 10 & Lao People's Democratic Republic & 62,06 & 116 & - \\
\hline- & Timor-Leste & - & - & \\
\hline
\end{tabular}

Source: Sachs et al., (2020).

Table 3: Indicator Performance of the Goals that far from the Goals Achievement

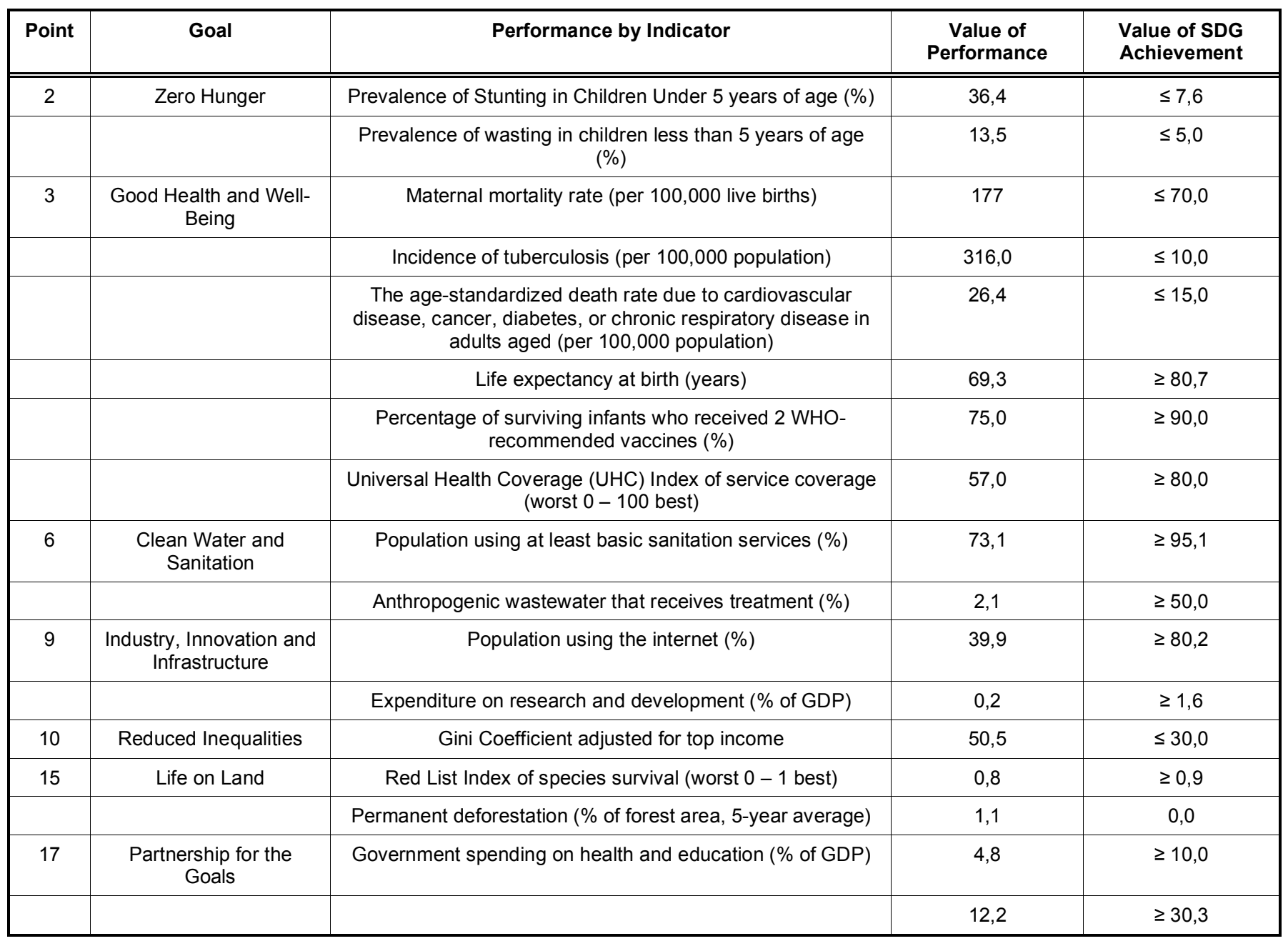

Source: Sachs et al., (2020).

atmosphere because the impact investors give the influence to the sustainable development goals achievement as a field-level frame. Investment takes part as catalytic by financing socially and sustainably the programs, projects properties, and enterprises (Castellas \& Ormiston, 2018). Investment, especially 
Foreign Direct Investment (FDI), influence the country's economic growth and sustainable development goals achievement. FDI can bring impact on Gross Domestic Product (GDP), exports orientation, the inflation rate, population control, life expectancy at birth, primary school pupils, infant mortality, total health expenditure per capita, total tax rate, internet users, and residential consumption of the electricity (Tvaronavičienè \& Lankauskienè, 2011). From these FDI positive impacts, it is not surprising that the Indonesian government has the ambition to create an Omnibus Bill on Job Creation, which aims to create an investor-friendly economic climate.

October 6, 2020, Indonesia Omnibus Bill on Job Creation set to be passed into law by the House of Representatives. It created a wave of resistance from various circles of society. However, this also happened in some countries that have enacted the omnibus bill. A wave of reaction is a natural thing for democratic countries. In June 2012, the House of Commons of Canada had enacted The Jobs, Growth and Long-Term Prosperity Act or known as Bill C-38, which was gained criticism and rejection from Canadian people (Cattapan \& Cohen, 2013). On January 23, 2012, US Republican Representative Tom Marino introduced in the US House of Representatives Bill HR 3806, The One Subject at a Time Act, which required ending the practice of omnibus bill. Nevertheless, this bill has failed to be passed (Massicotte, 2013).

With the complexity of the social system in a country, it is hard to be expected that the breakthrough of the new approach use in the legal system, will be accepted easily by the community. It is exacerbated by the international pressure and demands that bring social changes, which cannot be followed by society's readiness to accept these changes.

Nevertheless, the omnibus bill still promising good potential in the legal system. Notwithstanding, it has to be followed by a long process to make this bill near the perfect state. Here the author wants to convey that when the government wants to implement an omnibus bill, the opportunity for changes to the bill must always be wide open.

\section{CONCLUSION}

A long winding road to sustainable development goals achievement forced the countries to hit the breakthroughs that significantly impacted their countries. To build the country towards sustainable development goals, we cannot deny that economic interests take part in the process and hold the key in the adaptation of goal-attainment in the social system. The use of the omnibus bill has the potential to organize several types of regulations related to the seventeen UN SDGs into one legal umbrella. However, this was hampered by a wave of rejection that occurred after the omnibus bill was passed. This happens because the public is not ready to accept the changes brought by the political policies in the omnibus law. In case the government wants to use the omnibus bill, the omnibus bill should be open to legal changes demanded by the public towards the improvement of the omnibus bill.

This article contributes theoretically to a study to explore the opportunities and urgency of using the omnibus bill to address problems in employment in Indonesia. Theoretically, furthermore, the main contribution of this study is how the omnibus bill has the potential to help countries achieve the UN SDGs. Practically, in the implementation stage, the findings found a natural phenomenon that a political will contains economic interests in the adaptation process, as is the case with the omnibus bill in several countries.

The limitation of the study lies in that there is a possibility that a law like this will invite resistance in its implementation due to people's unpreparedness in accepting changes brought about by the political policies contained in the controversial omnibus bill. Therefore, the government must ensure that the omnibus bill is open to the opportunities for change that are requested by the public to perfect the omnibus bill.

Future studies are expected to analyze the progress of this Omnibus Law, and verify gaps in its success and weakness in its implementation. Further research is also expected to analyze the economic aspects of law and legal politics to support investment acceleration and ease of doing business in Indonesia.

\section{REFERENCES}

Akhlas, Adrian Wail; Ghaliya Ghina; \& Aritonang, Margareth S. 2020 Indonesia Delays Deliberations Over Labor Issues in Omnibus Bill Amid Backlash. Jakarta: The Jakarta Post. Posted April 25, 2020, 09:32 AM. Retrieved October 4, 2020 from https://www.thejakartapost.com/news/2020/04/24/govthouse-delay-deliberations-over-labor-issues-in-omnibus-billamid-backlash.html

BAPPENAS. (2017). Public private partnerships: Infrastructure project plans in Indonesia.

Bédard, M. (2012). Omnibus bills: Frequently asked questions. Library of Parliament. 
Castellas, E. I., \& Ormiston, J. (2018). Impact investment and the Sustainable Development Goals: Embedding field-level frames in organisational practice. Entrepreneurship and the Sustainable Development Goals, 87-101. https://doi.org/10.1108/S2040-724620180000008010

Cattapan, A., \& Cohen, S. R. (2013). The devil we know: The implications of Bill C-38 for Assisted Human Reproduction in Canada. Journal of Obstetrics and Gynaecology Canada, 35(7), 654-656. https://doi.org/10.1016/S1701-2163(15)30890-2

Chase-Dunn, C., \& Lerro, B. (2016). Social change: Globalization from the Stone Age to the present. Routledge. https://doi.org/10.4324/9781315632087

Elvinger Hoss Luxembourg Law. 2017. What remains of the Omnibus Bill of Law?. Posted July 4, 2017. accessed October 4, 2020, retrieved from https://www.elvingerhoss.lu/publications/whatremains-omnibus-bill-law

French, S., Leyshon, A., \& Thrift, N. (2009). A very geographical crisis: the making and breaking of the 2007-2008 financial crisis. Cambridge Journal of Regions, Economy and Society, 2(2), 287-302. https://doi.org/10.1093/cjres/rsp013

Futrell, J. W. (2004a). The Transition to Sustainable Development Law: Ninth Annual Lloyd K. Garrison Lecture on Environmental Law. Pace Environmental Law Review, 21(1), 179.

Futrell, J. W. (2004b). Defining sustainable development law. Nat. Resources \& Env't., 19, 9.

Gluck, A. R., O'Connell, A. J., \& Po, R. (2015). Unorthodox Lawmaking, Unorthodox Rulemaking. Colum. L. Rev., 115, 1789.

Hainque, M., \& Montin, C. H. (2011). Better Regulation in France.

King, D. C. (1997). Turf wars: How Congressional committees claim jurisdiction. University of Chicago Press. https://doi.org/10.7208/chicago/9780226436265.001.0001

Krutz, G. S. (2000). Getting around gridlock: The effect of omnibus utilization on legislative productivity. Legislative Studies Quarterly, 533-549.

https://doi.org/10.2307/440433
Maloney, N. (2011). Reform or Revolution-The Financial Crisis, EU Financial Markets Law, and the European Securities and Markets Authority. Int'l \& Comp. LQ, 60, 521. https://doi.org/10.1017/S0020589311000145

Massicotte, L. (2013). Omnibus bills in theory and practice. Canadian parliamentary review, 36(1), 13-17.

Organization for Economic Co-operation and Development. 2010a. Better Regulation in Europe: France.

Organization for Economic Co-operation and Development. 2010b. Better Regulation in Europe: Luxembourg.

Parsons, T. (1961). An outline of the social system. University of Puerto Rico, Department of Social Sciences.

Perrons, D. (2004). Globalization and social change: People and places in a divided world. Psychology Press. https://doi.org/10.4324/9780203646434

Rahman, Dzulfiqar Fathur. 2020. Govt Expects Deliberations on Job Creation Omnibus Bill to Finish in August. Jakarta: The Jakarta Post. posted July 15, 2020 12:22 PM/ Retrieved October 4, 2020, from https://www.thejakartapost.com/ news/2020/07/15/govt-expects-deliberations-on-job-creationomnibus-bill-to-finish-in-august.html

Sachs, J., Schmidt-Traub, G., Kroll, C., Lafortune, G., Fuller, G., \& Woelm, F. (2020). The Sustainable Development Goals and COVID-19. Sustainable Development Report.

Samboh, Esther. 2020. Guide to Omnibus bill on Job Creation: 1.028 pages in 10 minutes. Jakarta: The Jakarta Post. Posted February 24, 2020 10:07 AM. Retrieved October 4, 2020, from https://www.thejakartapost.com/news/2020/02/21/guideto-omnibus-bill-on-job-creation-1028-pages-in-8-minutes.html

Sinclair, B. (1997). Unorthodox Lawmaking: New Legislative Processes in the.

Tvaronavičienè, M., \& Lankauskienè, T. (2011). Plausible foreign direct investment'impact on sustainable development indicators of differently developed countries. Journal of Security and Sustainability Issues, 1, 27-38. https://doi.org/10.9770/jssi.2011.1.1(3)

WCED, S. W. S. (1987). World commission on environment and development. Our common future, 17, 1-91.

Received on 18-01-2021 Accepted on 16-02-2021 Published on 29-03-2021

https://doi.org/10.6000/1929-4409.2021.10.83

(C) 2021 Anggita Lumbanraja; Licensee Lifescience Global.

This is an open access article licensed under the terms of the Creative Commons Attribution Non-Commercial License (http://creativecommons.org/licenses/by-nc/3.0/) which permits unrestricted, non-commercial use, distribution and reproduction in any medium, provided the work is properly cited. 